\title{
And That's Not All: (Sur)Faces of Justice in Philosophy of Education
}

\author{
Marianna Papastephanou
}

check for

updates

Citation: Papastephanou, M. And That's Not All: (Sur)Faces of Justice in Philosophy of Education. Philosophies 2021, 6, 10. https://doi.org/10.3390/ philosophies6010010

Received: 10 January 2021

Accepted: 3 February 2021

Published: 7 February 202

Publisher's Note: MDPI stays neutral with regard to jurisdictional claims in published maps and institutional affiliations.

Copyright: (c) 2021 by the author. Licensee MDPI, Basel, Switzerland. This article is an open access article distributed under the terms and conditions of the Creative Commons Attribution (CC BY) license (https:/ / creativecommons.org/licenses/by/ $4.0 /)$.
Department of Education, University of Cyprus, Nicosia 1678, Cyprus; edmari@ucy.ac.cy

\begin{abstract}
Adjectives such as "environmental", "social", "cosmopolitan", "relational", "distributive", etc. reflect how scholars discern the many faces of justice and put several claims to, and claimants of, justice in perspective. They have also helped related research to focus on some surfaces of justice, that is, on spaces that invite justice, localities and formations, such as the state, social policies, social institutions, etc. within which ethical-political challenges unravel. Diverse philosophical perspectives enable context-specific explorations of (sur)faces of justice. However, I argue, there is more to the concept of justice than what perspectives (considered alone or in their sum total) allow us to view. To theorize how this surplus may be more discernible through stereoscopic rather than perspectival optics I first describe how educational-philosophical perspectives, old and new, discuss just education or education for justice; and then I critique the very notion of perspective on which scholarly work relies. Despite their merits, perspectival framings of justice fail to address the interconnectivity of various (sur)faces of justice.
\end{abstract}

Keywords: stereoscopy; postmodernism; posthumanism; context; discourse

\section{Introduction}

In his Call for Papers, Andrew Stables, the editor of this Special Issue on "New Perspectives on the Philosophy of Education", welcomes new educational-philosophical perspectives. He illustrates them with these examples: "gender, deep ecology, non-Western belief systems, posthumanism, and semiotics". New perspectives, the reader extrapolates, are desirable for many reasons. They move beyond the established range of philosophies (e.g., Anglo-American, Continental) that have been transferred to educational philosophy. They provide their own critical tools for what should guide educational policy and practice. These perspectives have not been (fully) mined, they promise a renewal of the field and, as I would put it, they deserve a discursive justice ${ }^{1}$, that is, they should have a fair chance to be aired and to occupy scholarly discursive space. How and where could/should ideas be aired is itself another issue of discursive justice. In eras celebrating performativity, educational-philosophical perspectives acquire discursive power when they engage major new philosophical trends and become established within a range of major, high-impact academic sources. New perspectives should shake such hegemonies by moving beyond what is "commonly encountered in the major journals" (here I adapt a phrase from the Call for Papers to the politics of a new perspective). And, I add, initiators of different perspectives should also enact this shaking of hegemony by valuing the opportunity to air their ideas outside the very category of a major journal and its disciplining and disciplinary role in scholarly research.

New perspectives are timely, concludes the Call for Papers, "given that educational thinking in much of the world is driven by a narrow performative agenda with scant attention to foundational issues". In my view, justice is such a foundational issue (which has,

1 By 'discursive justice' I mean the justice which concerns what our discourses ought to take into consideration, what they ought to include and/or make it endure. 
however, received much global emphasis—and often lip service-rather than inattention). Claims to advancing justice have been incorporated in many educational policies and practices, regional and worldwide, and also in many critical perspectives on them, old or new. Some of the new perspectives that are singled out in the Call for Papers (e.g., gender, deep ecology) are directly related to claims to justice, while other perspectives (e.g., posthumanism, semiotics) have an indirect though indisputable relevance to justice. However, despite their real or assumed newness, or precisely because of it, new perspectives also tend to become modish and, worse, new complacent orthodoxies and master discourses. And they are no less perspectival than older ones in capturing only some injustices in the world, that is, in making a list of glaring world pathologies stand out, "sexism, racism, environmental disaster, etcetera", and rarely rendering visible what substantiates the "etcetera".

Be that as it may, considerations of newness and of the relationship of education and successive philosophical perspectives will be kept in view in this paper. But my aim is, rather, to concretize what I have elsewhere [1] introduced as a "stereoscopic" optics $^{2}$ and conception of justice in, for and through education. To this end, I carry out a literature review to canvass how justice has surfaced in the "major" journals of educational philosophy. This surfacing corroborates Stables' above-mentioned implicit or explicit claims about old and new perspectives competing for discursive space. It indicates why we may need not just new perspectives on the foundational issue of justice but also new conceptualizations of how the face(t)s of justice intersect or should synergize. More, a stereoscopic optics may render visible that, when justice is the issue, the very metaphor of "perspective" should be explored, its pictorial force should be contested and its unconditional educational-philosophical valorization should be revisited.

Now that the rationale of the paper has been roughly sketched, and if I may accommodate an academic-autobiographical touch here, I would like to conclude my introduction by adding this: a paper on justice, with the inconclusive "that's not all" caveat already in its title, feels to me like a belated fuller response to a question that Stables had asked me back in 2014 at an official academic event. The question was: "what do you mean by "justice'", "which of all the meanings that justice has in diverse theories is relevant to your presentation"? My answer then, that is, over six years ago, was tailored to that presentation and to the circumstances of an aural and brief exchange of ideas; hence my feeling that, with the present article, I am giving now a more elaborate, written response to Stables' question then. Still, this answer is as inconclusive as the older one and as any "etcetera" in the infinite chain of world injustices (material and symbolic/discursive) would be.

\section{The "That's Not All" Caveat}

This paper, then, ventures to evoke how justice and its many faces appear in major educational-philosophical journals and to indicate an alternative optics on justice and education. The "that's not all" of my title also has many faces, two of which are already discernible: a section-length literature review within an article does not exhaust the venture; and, since "major journals" are my main sources, the venture itself hardly covers enough material to do justice to contributions to educational philosophy through other journals, books, proceedings, etc. This does not affect the objectivity of the review because the material discussed in this article is indeed representative of how justice is tackled in philosophical-educational sources generally. But I acknowledge that an inclusion of all sources is not possible and that the criterion of major journals is the most relevant to this article (as its aims are defined in its introduction) and also harmless to the overall project. For, the faces (categories) of justice that this article will contain are indeed those that stand out everywhere in the field. In addition, another sense of "that's not all" concerns my reading of the material that I have selected: for reasons of focus and

2 I use the technical term "optics" (related to light and sight regulation in physics) for reasons that will become clearer later on in the section where I will contrast "stereoscopy" to "perspective". "Optics" comes from the Greek word "optikon", meaning what is related to vision, visibility, lens and appearance. Nowadays, the term has entered the political-philosophical vocabulary especially to designate aspects of an idea or action that relate to public perception. https: / www.merriam-webster.com/dictionary/optics (accessed on 22 January 2021). 
relevance to this article's aims, I do not critique how each article advances research within its specific educational-philosophical purview. Therefore, my engagement with my sources is descriptive; regrettably though unavoidably, it is not a head-on dialogue with each author. What is more, much of what the selected articles contain will remain outside my scope, since, inevitably, my intention cannot be fully to describe each intervention but only to make some points about justice in educational theory and philosophy. And what I present as an author's account is certainly not all that the corresponding author has done. The authors have done much more than what I can register here. But the significance of their interventions concerns more specific contributions to the particular issues that they raise and do not quite touch on the "broad picture", that is, on the meta-theoretical optics of this paper. Therefore, again, the inevitably limited engagement with the sources does not affect the objectivity of the review and the categories that have emerged from: engaging with articles which put justice centre stage as their main topic (and do not just make an en passant comment on it), and examining how the noun "justice" is predicated through adjectives. The adjectives that dominate in the sources have formed the selected categories of justice not arbitrarily but because they determine which face of justice is the main concern (and purview) of each article.

For reasons of consistency and relevance, I have limited my literature review to journals which host almost exclusively educational-philosophical (and not empirical) works on justice and education. The journals are: Journal of Philosophy of Education, Ethics and Education, Educational Philosophy and Theory, Studies in Philosophy and Education, and Educational Theory. To further narrow down my material through formal criteria of inclusion, I have taken into account only articles with the term "justice" in their title and with a full engagement with justice throughout. I have not used any temporal criteria of inclusion (e.g., date-related search limits). After collecting and reading the articles, I organized my description in virtue of how justice becomes determined through adjectives or through a main adjective such as "distributive", "social", "global", etc. All articles, even those which do not contain an adjective in their title, engage in their main text with justice in an adjectival specification, for example, they engage with distributive justice, or social justice, educational justice, etc. Thus, predictably, many articles which relate to justice only tangentially will remain out of range, so to speak. Still, I hope that this caveat about limits mitigates the unintended, discursive injustice of my paper to the material that is left aside.

However, there is yet another sense of "that's not all", one that I would like to anticipate and emphasize already at this stage of my paper: the (sur)faces of justice that reflect justice-related situations in the world drastically exceed what notions of justice dominate our field or have, at least, carved a niche within it. More simply put, what is theorized in our field as a situation inviting justice is only what falls within the scope of the corresponding specific perspective; the whole set of instances of theorized justice does not exhaust the multiplicity of real-world situations relevant to justice and to just education. To give my favourite example here too (for I have given it repeatedly elsewhere [1]), most educational philosophy thematizes challenges of social justice. That is, it explores political normativities territorially and as social relations (e.g., inclusion of the Other-the poor, the disadvantaged, the racially othered, the gendered other, the migrant, and so on-within the classroom or within the country). This leaves out of range other facets of justice (political qua related to future politics and to visions of the ideal polis, cosmopolitan qua related to international relations, global-environmental, etc). And it does so from a methodologically statist/nationalist perspective, that is, from the single-focused perspective that concerns the local Other or the Other ashore, the compatriot or the arrivant, the person to be "accommodated" in our schools, in our sociality, in our groups, in our political spaces and in our public documents and policies. Other Others (human and non-human), those remaining in other spatialities, seem to be beyond justice (in, for and through education). Those dying or destroyed in seemingly remote spaces which are, however, entangled with our spatialities in complex relationships of accountability (historical or current), almost never become examples (I would say, metonymies) of challenges of justice for us in "major- 
journal" educational-philosophical publications. True, one might counter-argue, most faces of justice (especially those which concern political rather than interpersonal challenges) presuppose and require political authority and the power that a state exerts within its province. But my response is that we must not forget that a state also has external affairs. Also, a state takes measures (even if seemingly of local, internal affairs relevance), some of them environmentally significant or detrimental, that affect the whole world and not only its citizens or citizens-to-be. For instance, an issue that does not come up at all in educational-philosophical literature as an example of injustice, as a major problem of justice and as missing from our taught material on environmental justice is that much toxic e-waste of major Western countries is dumped in poor countries [1]. Such an issue remains invisible when the perspective for considering injustices and claimants of justice focuses on the social, that is, the space that is demarcated by the state's borders and by the relations and claims of justice within it. The agent may still be the state (though consider precisely what this means for the United Nations (pro-)visions of international right), but the recipients or claimants of justice should not be visible only when they inhabit the state.

I in no way mean to downplay or minimize the valuable contributions to justice and to just education that various perspectives make possible and advance. But the intellectual traditions that we have inherited and, worse, those that we have selectively transferred to education and rendered vogue, even our newest, posthumanist perspectives, lack the required emphases (often even the conceptual means) for spelling out the challenge that, say, a recent event such the Nagorno Karabakh war (and its genealogy) constitutes for justice and education. Likewise with the example of whistleblowers such as Julian Assange, Edward Snowden, Kathryn Bolkovac and Katharine Gun who have admirably complicated the relationship of loyalty and justice usually assumed in the most dominant philosophical trends (which neatly associate loyalty with partiality and justice with impartiality). Indeed, the issues of justice that whistleblowers have raised through their complex loyalty to justice cannot be channelled into our main educational-philosophical specifications of justice. To offer one more example: the global educational-philosophical eye has recently commendably turned to the issues of justice that the Black Lives Matter movement has importantly raised and engaged many perspectives to theorize racial injustice within a territory. But it has never zoomed in the injustice to the Marshall Islands, to the deaths, illnesses, population displacements and environmental destruction to which the US nuclear policy led between 1946 and $1958^{3}$. No perspective was utilized to theorize that Marshallese lives matter, how this example should mater for education for justice and what perspectives this would need for becoming visible and theorizable in educational philosophy. Hence my caveat above that there is far more to justice as a real-world challenge than what surfaces in the virtual (indeed, viral) world of educational-philosophical research disseminated through major journals and of data-based educational research propagated through databases of high-impact factor journals.

So, which faces of justice surface in our field and how do they become visible?

\section{Face(t)s of Justice}

Zooming in to the educational-philosophical visual field that covers justice we observe that what is represented, what passes the filter of our field (now meant as discipline), mainly comprises: distributive justice; educational justice; social justice; democratic justice; relational justice; and postmodern, multiple justice. It is, then, around these adjectives that this descriptive section will revolve.

\subsection{Educational and Distributive Justice}

Articles on educational justice often rely on liberalism versus communitarianism exchanges and, in such works, diversity and advantage are debated. Sometimes, an unam-

3 See, for instance, David Vine [2] (pp. 51, 64, 183). Vine adds: "Henry Kissinger once said of the inhabitants of the Marshall Islands, 'there are only 90,000 people out there. Who gives a damn?'" [2] (p. 183). 
biguous diversity even becomes a stopgap or placeholder notion of unquestioned value. However, William New and Michael Merry complicate the assumption "that diversity serves as a good proxy for educational justice". They point out that "a disproportionate share of the benefits that might result from greater diversity often accrues to those already advantaged" [3] (p. 205). More generally, it is noteworthy that difference and diversity are also put centre stage by postmodern perspectives on justice: "a postmodern understanding of justice requires a commitment to difference. It is only in this search for difference that marginalized voices will be heard" [4] (p. 564). Yet, such convergence of liberal and postmodern perspectives on the issue of diversity and justice never constitutes a springboard for analysing the rapprochement of these perspectives more deeply. Indeed, would educational and distributive justice not benefit from, say, the French continental perspective and its philosophical sources? Do perspectives other than the Anglo-American have nothing to offer on this issue? Evidently, educational philosophy has not considered this possibility; no article discusses together, in critical dialogue on the issue of distribution, say, John Rawls and Alain Badiou. Likewise, say, with African philosophy perspectives that also remain largely non-utilized. To anticipate my critique of single-focused perspectives let me state that a stereoscopic optics would inspire vigilance and awareness of how insights from diverse perspectives placed alongside in simultaneous visibility might illuminate issues of distribution differently. It would show, for example, that distributive justice reflects much more than outcomes, advantages and equality. It involves deep ontoanthropological assumptions (unacknowledged by political liberalism) about what effects existential asymmetries. It also involves questions of how the deserving and undeserving are defined [5] - questions that political liberalism typically sweeps under the rug when they touch on comprehensive theories of humanity and non-humanity that liberalism thinks that it has surpassed.

At any rate, in most bibliography, educational justice is explored from the prism of outcomes. Distributive justice and educational justice are often co-examined since the former is considered a condition or enabling factor for the latter. There is thus a tendency to understand justice as "demanding equal outcomes" [6] (p. 1) and just education as preparation for outcomes such as "participation in the economy", "democratic citizenship", "attainment of knowledge or intellectual ability", "ability to pursue a good life" and "ability to formulate and act upon one's aims" [6] (p. 3). Christopher Martin [7] (p. 165) challenges this tendency because it renders knowledge a means to non-epistemic ends. He pertinently claims that the "intrinsic value of knowledge has relevance for educational justice" and that "knowledge has educational value for reasons independent of specific political purposes or goals" and beyond "its usefulness in bringing about other goods" [7] (p. 166).

In another article, Martin and Tal Gilead [8] (p. 543) find "the relationship between the fair distribution of goods in general, and the intrinsic, or distinctive, value of educational goods in particular" highly important for educational justice and for questions of resource allocation. In fact, educational justice is usually viewed "in terms of the relationship between educational resources and educational outcomes" [6] (p. 3). The central role of education in determining individuals' life chances makes it "a central issue for distributive justice" [9]. If distributions of educational resources are uneven, then "whatever inequalities that arise between students as a function of their education will be unjust" [6] (p. 3). Distributive justice in education regards students as recipients of distributive goods and education as a distributable good. Equality is then a matter of providing educational resources in a way that respects equal entitlements.

Typically, "at least three general accounts of educational justice" are distinguished: "fair equality of opportunity in education; luck egalitarian educational equality and educational adequacy" [10] (p. 466). To each corresponds a different task and a related obstacle: the first aims to control arbitrary influences (such as family backgrounds) on fair opportunities; the second treats as unjust all arbitrary disadvantages such as the so-called "natural talents" and differences in the degree of the child's preparedness for education through parental upbringing; and the third emphasizes sufficiency standards rather than equal 
opportunities. All three view "the importance of equal access to primary education as central to justice" [10] (p. 467). Obstacles to educational and distributive justice are also typified as conflicting interests [9], unpredictability [11] (p. 439), natural contingencies [12] (p. 473) and even talents [13], along with different interpretations of what talent means.

Talent is of major importance in debates about "the justice of school systems" [14] (p. 1) and about distributive and educational justice. This attributed importance is evident also in the number of articles that we find in our journals on this matter. But as K. Meyer mentions, "it is striking that despite the centrality of the notion of 'talent' in these debates, the concept is hardly ever explicated". Recent publications such as Meyer's aspire to remedy this. One such publication plausibly argues that "regardless of how we understand the notion of talent and its justificatory function in a theory of distributive justice", the very serious "moral problems of practices of talent ascription" should deter us from relying "on them to ground the distribution of educational prospects" [15] (p. 1). Another article pertinently points out that despite the received view "that there are such things as natural talents, more than 20 years of research suggests the opposite" [16] (p. 1). If talent is attributable to a combination of factors other than naturalness or innateness, then, there are major implications for various theories of distributive justice and for real-world distributions.

Many articles which discuss distributive and educational justice refer to Harry Brighouse, who sees as a primary concern of justice the correction of unfair social inequalities between individuals and the provision of education for autonomy. Samara Foster, for instance, has charged Brighouse's faith in the egalitarian potential of school choice with over-confidence, questioned its political feasibility and characterized school choice as "a flawed educational reform" that worsens prospects of social justice [17] (p. 291). More recently, Brighouse has explored inter alia "goals and principles that constitute social justice in education", whether "socio-economic segregation of schools" is a social injustice and to what extent ameliorating social justice in education "is an efficient strategy for attacking educational injustice" [18] (p. 576). His own view of educational justice nests within an egalitarian perspective that "emphasises not equality, per se, but benefiting the least advantaged" [18] (p. 578).

Who is recognized as disadvantaged is broadened by Ben Kotzee who considers symbolic rather than material forms of injustice. Interestingly, his intervention has, in my terms, something stereoscopic in his making visible how another perspective on justice illuminates differently the distributive face of justice. He draws from Miranda Fricker's perspective on how epistemic injustice affects members of groups of low social positioning. Members of such groups are not only "materially disadvantaged; they are not believed and are not accorded a voice" [19] (p. 342). Kotzee stresses how a change in focus makes things about justice look different and requires different measures: "once we focus on the fact that it is knowledge that is distributed in education and not jobs, the justice question begins to look different. And not only does the question look different, but the philosophical tools appropriate for answering it change too" [19] (p. 340). Hence his normative claim that questions "of educational justice should be approached not from a distributional, but from an epistemic perspective" [19] (p. 332). Parenthetically, let me mention that from my stereoscopic optics there should be no such drastic choice. Educational, distributive and epistemic are faces of justice whose synergy and tensions do not impose an either/or dilemma as evoked in the structure: "should be approached not..., but from...". Anyway, critiquing inter alia Harry Brighouse's position, Kotzee emphasizes the significance of the "virtue of epistemic justice" for "theories of educational justice" [19] (p. 331).

It is true that, as Kotzee remarks, "contemporary thinking about social justice" makes "the role that the educational system plays in fostering social justice (or injustice)" stand out by drawing heavily on distributive justice [19] (p. 331). Indeed, many articles dovetail educational/distributive and social justice. However, social justice, which is the most frequent keyword of educational-philosophical titles and article contents and has the lion's share of the educational-philosophical interest in justice, is very often approached from other philosophical perspectives. This is what I turn to next. 


\subsection{Social Justice}

A "meaningful and useful account of social justice" is sometimes searched for in "civic republican theory" [20] (p. 167) or in national affirmations of social justice visible in efforts to teach social justice in schools. This is problematized by James Scott Johnston who argues that the roles of the school "towards defining social justice, implementing a social justice curriculum, and monitoring the effectiveness of such a curriculum" are unclear [21] (p. 119). Shilpi Sinha's [22] article, which is another example of an exclusive focus on social justice, also qualifies the educational theory literature on classroom hospitality by adding the intricacies of the positioning of the educator and issues of racialization.

From another classroom practice perspective, committed to enriching "the scholarship on and teaching of social justice education" with more insights from Dewey, Peter Nelsen investigates "student resistance to engagement with social justice issues" and concludes "that resistance is an opportunity for growth" [23] (p. 231). On her part, Catherine Ward [24] uses theories of justice operating beneath the notion of equity to deconstruct the received view on equitable treatment in classrooms and to turn attention to refugee and asylum-seeking students. David Bridges [25] also focuses on social justice, Barry Bull [26] proposes "a theory of social justice in education" from a Rawlsian perspective to analyse "normative and factual disagreements" [26] (p. 141) and Sharon Todd indicates how "issues of social justice, equality and peace play into current educational policies, practices and objectives" [27] (p. 39). From another, Butlerian perspective, Michalinos Zembylas [28] tackles the pedagogy of discomfort through a framework of social justice where ambivalences of subjectivity construction complicate normativities of the "safe classroom" and of nonviolent ethics. In his most recent article, Zembylas explores the implications of "relational and political understandings of happiness in education discourses" for "remedying racial and social inequalities and suffering" [29] (p. 18). The co-examination of rights and social justice has its own niche in our field. For instance, in analysing aboriginal educational rights, Christopher Martin turns from rights to "a fair share of educational provision" to rights of authority over one's "developmental interests, including an interest in culture and identity". While examining "various justifications of aboriginal educational rights", Martin employs "a Habermasian justification that remains consistent with individual rights" [30] (p. 33).

The arena of social justice is often the university rather than the primary or secondary school classroom. Sarah Aiston raises issues of gender, equality and higher education [31], while Kotzee and Martin ask "who should go to university in the first place" [32] (p. 623). Through this question, they challenge the "technical, policy-focussed perspective" from which "current debates regarding justice in university admissions" tackle access to university [32]. Academia as an arena of justice becomes both nation-specific and global when Enslin and Hedge ask: "is it just to charge international students fees that are generally much higher than those paid by home and European Union students at UK universities?" They detect an ethical tension between the "avowed commitment" of universities "to social justice on the one hand and selling education to foreign students at a premium on the other". As a global justice issue, they argue, viewing "education as a global public good" compels a reconsideration of "the current fee regime" and the role of universities "in a competitive global economy" [33] (p. 107).

Academic research has also been a major focal point of educational-philosophical engagements with social justice; on this, Morwenna Griffiths' work has been most pioneering. Griffiths has directed the attention of educational research to social justice concerns for voice, representation and power. Critiquing Griffith's work Naomi Hodgson [34] argues that, by becoming increasingly mainstream in the field, the social justice agenda is co-opted by government rhetoric and thus loses its critical edge [34] (p. 560). Hodgson also critiques the assumptions about the nature of injustice that inform Griffiths' work and accuses her of an only limited following of poststructuralism. That is, Hodgson hegemonizes the poststructuralist perspective, since she wants to postmodernize or poststructuralize, so to speak, 
the notion of social justice, to tailor it to Lyotardian and Foucauldian discourses. ${ }^{4}$ This is precisely one of the perspectival hegemonic operations that, as I show in later sections, my stereoscopic optics questions and staves off. At any rate, more recently, Griffiths canvasses issues of social justice by critically discussing how "Rousseau and Wollstonecraft wanted education to produce social justice in the future" and benefit students in the present [35] (p. 339). Or, in collaboration with Rosa Murray, Griffiths engages posthumanist perspectives on social and global justice to "propose a phenomenological approach to ethics and justice" inclusive of "human and more-than-human parts of the world" [36] (p. 39).

Another important source for educational-philosophical research on social justice has been Iris Young's perspective. From Young, Sharon Gewirtz derives argumentation for a "social justice in education" "understood in relation to particular contexts of enactment" [37] (p. 69). She is interested inter alia in how "justice is enacted in practice" and how "concerns of justice are mediated by the other norms and constraints that motivate actors" [37]. Iris Young has also influenced Penny Enslin's [38] investigation of the "relationship between democracy and social justice" and "implications for education" [38] (p. 57). Yet, the logic and the vocabulary of social justice seem to be merely extended to the global sphere and to be deemed directly translatable into an idiom of international relations. Enslin extends Young's argumentation to global justice and expects "western feminists and their governments to do more to promote democracy and social justice globally" [38] (p. 57). Democracy and social justice are placed together by other perspectives too. Itay Snir and Yuval Eylon [39], for example, consider the "existing republican educational discourse" in light of "the distinction (and deep connection) between democracy and social justice" that is "central to Pettit's republicanism". In such light, current discussions appear lopsided, focused as they are "almost exclusively on education for democratic citizenship" and hardly touching "upon social justice". The authors also detect temporal flaws in the focus on "educating future citizens", rather than on "conceiving of students also as political agents in the present, and of school itself as a site of non-domination" [39] (p. 585).

However, democratic justice is sometimes educationally-philosophically examined independently from the adjective "social", as a self-standing designation of what counts as justice, and this is our next stop.

\subsection{Democratic Justice}

Two major perspectives, citizenship education and character education, theorize democratic justice differently. Citizenship education typically construes democratic justice as a social virtue "whose ultimate justification rests on the right to be treated justly" on grounds of institutional entitlements and procedural, democratically set rules. For character education theorists, however, justice is "a personal virtue, emotionally grounded in early childhood experiences", mirroring pre-institutional deserts prior to institutional entitlements [40] (p. 215). As Kristjánsson theorizes the relationship of these perspectives, character education wants to keep citizenship education in its proper place. It views it as a supplement to, but not a replacement of, the "moral basics"; democratic justice then becomes "a supplement to justice as a personal, emotional virtue" [40] (p. 218).

We find the association of democratic justice with appropriate emotions and ethics also in educational philosophies that are not easily placed within the above perspectives. For instance, democratic justice enacted in schools and cultivated through friendship is the main focus of Yusef Waghid's work on communicative, deliberative ways of engendering "inclusive teaching and learning practices in classrooms" [41] (p. 199). For the meaning of democratic justice, he relies on Amy Gutmann's conception of it as a set of capacities for a democratic way of life. Education in this notion of justice amounts to learning "to recognise equally the freedoms of others, to contribute towards private and public justice, and to be decent". Yet, this learning, argues Waghid, "cannot take place in university

4 This, to me, raises issues of discursive justice and of master discourse risks. Also, the risk that Hodgson associates with Griffiths' conceptions ("but instead risk contributing to an already familiar discourse" [34] (p. 565)) is also a risk faced by current Foucauldian discourses. 
classrooms without teachers and students acting as friends" [41] (p. 204). Educating for friendship becomes for him a most topical way for fulfilling the "promise of democratic justice on Africa" and for staving off "uncritical modes of learning which could further extend the violation of human dignity on the African continent" [42] (p. 182). Another interesting articulation of democratic justice from outside the hegemonic Anglo-American space is Moon's article on how "democratic ideals of equity and justice" in major Korean philosophical-theological concepts reflect an ontology where the principle: "my mind is your mind" aims to create "a new cosmic world" [43] (p. 1146). This relationality of ultimate unity could have relevance, in my view, for a relational justice as well. The latter, however, is often a philosophical-educational topic in its own right. Let me briefly illustrate it.

\subsection{Relational Justice}

Relational justice entails effects of justice on education that drastically differ from, say, those of distributive justice. Distributive justice cannot cover the ground of relational justice. As Dum aptly puts it, "one can imagine a student lavished with resources yet deprived of interpersonal relations that are necessary for developing a healthy personality and interpersonal skills that are not intrinsically correlated with personal academic achievements" [6] (p. 10). This is another instance of the educational-philosophical optics turning stereoscopic in the following sense: Dum places the facet of distributive justice alongside that of the relational justice that is often hidden when in most related discourses the distributive stands out and is put in perspective. In so doing, Dum helps us see how the distributive facet looks when viewed along with the relational facet and what tension of justice this reveals. In a somewhat similar vein, though from a different perspective, that of Paul Ricoeur, Watts connects justice to politics by directing the reader's eye to "the responsibilities of the citizen in society to other citizens and to the state" [44] (p. 307). The relational aspect is evident in that, for Ricoeur, justice "is preceded by indignation in the face of injustice" [44] and thus by affective relational entanglement of the self and others.

Clarence Joldersma also begins from the tenet that "education involves an originary ethical relation to the other", beyond "the self-directed character of the striving to live" [45] (p. 441). We may extract the following relational elements of justice: "treating each other responsibly"; justly comparing "between others, even though each is unique and incomparable"; "consciously deliberating"; and being thoughtful about "all the ethical claims that each other makes on all the others, situating the ethical relation into a social matrix, the responsibility one has to each other in the context of all the others" [45]. Yet, relational justice sometimes requires restorative justice. Wendy Drewery examines restorative justice and theorizes it as aiming to a "healthy relational functioning" for offended and offenders. As concerns schools, restorative justice serves, beyond conflict resolution, the production and maintenance of respectful relationships [46] (p. 191).

I have so far shed light on many face(t)s and surfaces of justice. I have stereoscopically rendered them visible simultaneously, in one literature review, and placed them one after the other. Seen together they already indicate this: though most articles focus on one or two facets of justice, the big picture that they construct in their linear togetherness shows that justice is multiple, it looks different depending on one's lens and it is regarded in educational philosophy (just as everywhere) from multiple perspectives. In our field, the multiplicity of justice, in the rare instances of its thematization, is associated with varying contexts, it reflects a valorization of diverse perspectives and it is placed within the postmodernist setting.

\subsection{Postmodern, Multiple Justice}

Precisely that justice is "context-dependent and multiple" [4] (p. 561) leads Claudia Rozas to examine how Freire's conception of justice may cope with its postmodern critiques. Still, we see that, for many postmodern educational philosophers, social justice remains hegemonic even within the postmodern setting. For instance, Barbara Applebaum's article, which utilizes Judith Butler's conception of subjectivity, focuses on social justice. Exploring 
white complicity, she shows "the implications of Butler's conception of self and agency for social justice pedagogy" [47] (p. 59). In her 2007 article, Sharon Todd [48] disconnects justice from epistemic issues of truth by relying on the perspective of a single major philosopher, Jean-Francois Lyotard, whose views on justice having no basis on facts or truth become in her article, probably unwittingly, the only "truth" that is allowed to an educational philosopher faithful to postmodernism. The single-focused attention to one or two major postmodern figures is also evident in Christine Winter's utilization of Jacques Derrida and Emmanuel Levinas' work on justice to trouble the British curriculum framework and discourse of knowledge that related policy texts and reforms promote [49] (p. 276). On his part, Benhur Oral [50] multiplies his scholarly normative sources. Žižek, Meillassoux, the whole of PoMo (postmodernism) and Buddhism help him investigate whether justice is possible at an ontological level.

PoMo is supposed to undo dichotomous thought. However, it often creates its own dichotomies when justice is the issue. Thus, when Todd discusses just education through human rights' intricacies, she asks a question that could have polarizing implications: "How might we think beyond an education that merely seeks to inculcate knowledge, toward a just education that provokes insight into the conditions of freedom, justice and responsibility themselves?" [48] (p. 593). But is the inculcation of knowledge never a precondition of justice? A stereoscopic optics (see later) complicates such assumptions because it presupposes that it is through uncomfortable knowledge that overlooked injustices are brought to the fore and destabilize the hegemony of what has already unlocked the doors of perception. Anyway, from Naoko Saito's perspective (following Nussbaum), justice is conditioned on the cultivation of political emotions that involve "cognitive appraisal" and presuppose "normative commitments". And when Saito's perspective turns Cavellian and Emersonian, it combines Nussbaum's notion of political emotions with a perfectionist education that critiques "distributive justice for 'perceiving the dissent as a deviation from the norm" to envision a society that copes with "the disturbing moments created by impish words" and allows "space for the unknown, the unsaid" [51] (p. 486).

Without addressing directly either the character education perspective or Saito's discussion (both of which extol the relevance of emotions to justice), Liz Jackson complicates the reliance on emotions and singles out "tensions between discourses of emotional care and compassion and rational duty to social justice" [52] (p. 1069). Then again, rational duty is articulated through rational discourses whose rational practices, as Mark Weinstein argues, have their own failings such as the disregard of some injustices [53] (p. 378). The politics of discourses on (in)justice may have often been considered through the socialjustice prism of according a political voice to marginalized groups, but Amanda Keddie's postcolonial perspective problematizes group identity. She points "to the significance of people and their politics, rather than their membership to a particular identity group" [54] (p. 311). On his part, Weinstein refers to how an injustice suffered by a particular identity group illuminates discursive ills: "the injustice that resulted from the marginalisation of women points to a pathology in discourse frames within which the injustice was invisible". For him, "critique requires the interrogation of such discourse frames and the exposure of those elements that supported, whether unconsciously or with complicity, the disregard of blatant injustice" [53] (p. 378).

Of special relevance to my approach in this article is that Weinstein raises issues of disregard (I would say of blindness) as crucial to detecting and critiquing injustice, but, while he sees such issues as matters of social justice, I see them as matters of a discursive justice that is in a complex intersection with many other facets of justice, the social being only one among them. In fact, discursive injustices affect, though they do not necessarily produce, various facets of justice along with their synergy and the cracks in the whole that their synergy involves. This whole makes the concept of justice (with no adjectival specifications) intelligible and communication on justice (in such abstraction) possible. Intricate relationships of faces of justice and their forming a whole exemplify, as I argue next, why we may need more than just multiple perspectives. Perspectives make different 
issues and faces of justice surface in a disconnected, single-focused manner. Often, the most prominent face(t) obscures and hides the face(t)s behind it. Hence we may need a complementary view, the stereoscopic optic that is not reducible to the metaphor of perspective.

\section{Educational-Philosophical Perspectives}

Focusing closely on our educational-philosophical visual culture concerning justice I have briefly, indeed, skeletally reviewed what is typically perceived as inviting attention from a major justice perspective. Zooming out now let me make the following comments: though itself susceptible to the politics of (in)visibility, an overview (such as the above literature review that enacts a stereoscopic placement together of faces of justice) helps us reconsider what we view and what remains invisible, out of range, and unspoken. Articles singly-focused on one perspective (and understandably so, since scholars have specific research interests and aims) make visible limited faces of (or sets of questions about) justice. True, as I have already indicated, there are already in our field some stereoscopic moments where a specific handling allows the simultaneous visibility of more than one face of justice and the surfacing of more than one perspective in a single paper. However, even these still operate with either/or perspectives. In addition, there have been no efforts to examine the interconnectivity of (sur)faces of, and perspectives on, justice and what this may make more visible. I have given a couple of examples of invisible matters of (in)justice much earlier in the article and I have discussed this more extensively elsewhere. Hence I turn to some general remarks on the (in)visible in our discourses. In educational philosophy, "justice and education" are placed in a relationship that invites a certain mental activity, a rethinking. The task which is often promised is to rethink, through justice, what we offer as ethical-political education in contemporary societies. But these two nouns, justice and education, are also put in an adjective-noun relationship when justice takes an adjectival form and the construction now becomes: just education. In other words, when the adjective "just" qualifies education, the latter ceases to be "just" education (merely, simply education), e.g., its value troubles performative aspirations of our times just to turn students into achievers. It is an education as it should be, and this "should" is demarcated by whatever contents the educational philosopher gives to the adjective "just".

Still, just education is not quite the same as education for justice. And neither of them is reducible to justice in, for, and through, education. Such meta-theoretical distinctions are often missing in the approaches that we encountered in the literature review. As a qualifier of education, the adjective "just" relates to education for justice, since an education for justice must be just in some sense, after all. However, the term "just education" evokes the intra-mural and not the world outside. An education which treats all students equally in the classroom may be just only partly; it is not just in the generic sense that justice has when we refer to it without specifying it with adjectives. Just education does not address the full scope of a justice that is composed of a variety of adjectives that are irreducible to one another.

The following walks us through to the issue of a generic sense of justice. In our field, the value of justice is undisputed. Proof of this is inter alia that, when we put justice centre stage, we seldom if ever justify such an act. We hardly feel like defending our interest in, or commitment to justice, let alone compelled to explain "why justice?" and "what is justice?". Certainly, the specifics of justice, e.g., what counts as just, are considered debatable and deconstructible. However, despite its terminological elusiveness, justice as such remains normatively unchallenged. I have not encountered articles that argue for injustice or qualify justice to avoid its sliding into a pernicious idea or to protect their discourse from criticisms that promoting justice smacks of something bad. Justice is often employed in the articles as a free- or self-standing concept. The undisputed normative value of justice entails that, even when adjectives (environmental, global, social, etc.) are added to the noun "justice" these do not qualify its normativity; they just specify and focus it. 
Nevertheless, adjectives operate crucially in educational-philosophical articles on justice. They operate politically and in ways non-theorized and unexplored in (educational) philosophy. Adjectives differentiate contexts or modes of applicability of justice. They narrow down the scope of justice, singularize and instantiate what space/surface invites justice, who should have the right or power to place herself in the position of the wronged, the claimant, and possibly, the recipient of justice [1]. This raises important questions concerning the self-standing and general character of justice as a qualifier of ethico-political education: what justice helps us rethink education? And what justice is served in, for, and through education? Is it the social, the global, the environmental, etc.? Could it be just any kind of justice (hence the generality of the free/self/standing justice) or should it be the sum total of all face(t)s of justice? Some articles engage perspectives for dealing with distributive justice; other articles specialize in a postmodern justice that, in its latest versions, allows for posthumanist considerations. There is nothing wrong with this division of labour. But I consider it a problem that perspectives are disengaged from one another and there is no dialogue with philosophical sources or figures outside the perspective. Even when educational philosophers step out of older perspectives to introduce something new, justice is approached through the lens of which philosopher had been left out and would have radicalized our thinking about justice. The philosopher (and the singular, corresponding perspective) then turns into a metaphysical deus ex machina who will take education by the hand to lead it to a better world. Worse, one face of justice (e.g., the global) is reduced to another (e.g., to the social and to its spheres of action such as education qua institution, migration politics, conflict-resolution-for-social-cohesion, social policy). By contrast, in our explorations of justice and education, we should seek to do discursive justice to each face $(t)$ and to its irreducibility to other face $(t) s$. Seen stereoscopically (as I argue later), the full normative power of justice lies precisely in the whole that is created by the synergy of its face $(\mathrm{t}) \mathrm{s}$ and surfaces and the involved cracks. It may be perfectly legitimate to talk about a generic justice (general and free-standing, with no adjectival specifications) so long as we keep in mind that the unity of the (sur)faces of justice that this generic sense implies is brittle, temporary and serves zooming-out purposes. The phrase "justice in, for and through education" adds the nuance that helps better specify a certain relationship of justice with education and avoid the risk of "just education" excluding extra-mural issues of justice.

However, my claims about a generic justice seem ill-fitting in the postmodern framework where justice is "context-dependent" and "there is no single justice based on a single set of principles that can be applied in all situations" [4] (p. 562). My response is first that a single justice does not compel a single set of principles; then, despite its value, this postmodern framework is trapped in perspectival optics at the expense of what I theorize as a stereoscopic optics of justice. To explain: context-sensitivity is valuable for putting issues of justice in perspective, that is, for showing the right relationship of visible facets of justice and decide which facet is applicable to which situation. It is valuable for putting the appropriate facet of justice centre stage (distributive justice has primacy over, say, restorative justice when the issue is the sharing of the socio-economic pie and its educational relevance, and not conflict resolution and settlement of suffered damages). But acknowledging the multiplicity and context-dependence of justice does not say much about how the multiple facets relate with one another and what their synergy, their tensions and the cracks of the whole they form when placed together may reveal. ${ }^{5}$

\section{The Stereoscopic Optic}

This section ends this article by explaining the difference between the optic/aesthetic metaphors of "perspective" and "stereoscopy". These help visualize how educational

5 I will not answer this "how" and this "what" in this paper, though I hope to have indicated some answers and it rests with the reader to explore them further. As such, these "how" and "what" are daunting tasks that could be undertaken by a whole community of educational philosophers and not by one person and dealt with through many writings rather than through one article. 
philosophy whose object is justice represents it, how it views justice and how it could alternatively view it. I am indebted to Mark Debono who, in personal communication, valuably suggested a source on stereoscopy [55] that has proved highly relevant to this task.

Perspective is a representational modality that involves "a homogeneous space that transparently locates and defines objects" [55] (p. 283). Stereoscopy was "a potentially subversive mechanical art" (268) based on an alternative representational modality that involved "an object-defined space of variable density in which object volume must be wrestled into being by an active spatial imagination working against incompatible visual fragments" [55] (p. 283). As a scientific toy, the stereoscope represented "not the form of objects in the external world, but rather the anatomy of seeing and the process of space-making" [55] (p. 264). It was a reflexive device that assembled space and produced volume [55] (p. 265). Therefore, "between perspective and the stereoscope there is a shift in representational paradigm" [55] (p. 283) from hierarchies of visible surfaces (hierarchies that regulate visibility by defining what stands out) to what I see as a different visual poetics. Adapted and applied to justice Bantjes' parlance entails correspondingly that: in perspective, justice always appears in one, or two, or, at most, three of its facets and surfaces in a homogenized (social) landscape; and, in "stereoscopy's mimetic realism" [55] (p. 282), justice in its volume has all its facets/surfaces visible in a fractured space. Hence, I add, thought through in such a way, perspective is not by definition as "politically correct", democratic and non-hierarchical as the (post-)modern polemics (against universalism) have so far presented and exalted it.

Context- and perspective-sensitive "critiques of modern understandings of justice centre around the problematic nature of a universal justice for all and the understanding of oppression as singular" [4] (p. 562). To do justice to the meta-theoretical strengths and weaknesses of perspectival contextualizations of justice (such as those presented in the literature review) requires separate, book-length engagement with each beyond the limits of this article. What is relevant here: philosophical perspectives on spheres of justice and context-/practice-based justice are valuable for obtaining more awareness of nuances and for zooming-in contexts where justice reflects a plurality of principles. Postmodern critiques of universalist justice certainly allow a better view on face(t)s of (in)justice concerning issues of gender, race, etc., within various social contexts. However, they fail to theorize the interconnectivity (and tensions) of such facets with other facets and with the different surfaces (interpersonal relations, inter-state-politics, international relations, Gaia) that host them or are shaped by them. As we have seen in the descriptive section, even in articles that draw on postmodernism, social justice has the lion's share of attention. Ironically, then, postmodern critiques view only injustices/oppressions that relate to a homogenized space (the social); by reducing all issues of justice to sociality they universalize a singular face(t) of justice, the social. They overlook the interconnectivity of faces of justice that is revealed by "zooming-out" optics of the stereoscopic kind. Zoomingout is also required for assembling surfaces of justice. The "stereoscopic" provides this zooming-out as the necessary temporary abstraction and distancing from what the eye is accustomed to viewing as unjust. Still, its connotations of fuller vision, as illustrated with interconnectivity and assembling of (sur)faces, add a zooming-in as a constant reminder that one face $(t)$ of justice is not reducible to another.

Educational-philosophical discussions of justice conform to the spatial conventions of perspective. We reach the same conclusion if we explore the question: How does the just subject (current and future) emerge from our field as an image? How is she sketched? By contrast, a passage from an 1859 essay on the stereoscope helps imagine justice and the just differently: stereoscopically, the mind feels round the object "and gets an idea of its solidity. We clasp an object with our eyes, as with our arms, or with our hands, or with our thumb and finger, and then we know it to be something more than a surface" [55] (p. 272). (In)justice becomes more tactile than purely visual; the (un)just is more embodied than mirrored. 
Instead of incriminating the universal or generic wholesale, this optic would explore the singular and the plural in synergy and tension. It would investigate how the visibility of issues of justice is enhanced when we obtain a sight of the "togetherness" of face $(t) s$ of (in)justice (environmental, social, cosmopolitan, etc.), their interconnectivity and their discrepancies. I think that what obstructs such explorations is not only the polemics that effect quick dismissals of anything suspect of universalism (and the postmodern inversion of the old dichotomous priority of the One over the Many) but also our current tendency to associate interconnectivity and interconnectedness with human global mobility rather than with conceptual relationality and plurality in unity and tension. A generic justice which emerges from a stereoscopic prism that places together its (sur)faces also does discursive justice to interconnections and fractures. My adjective "stereoscopic" qualifies the universalism of the generic self-standing conception of justice by producing a fractured whole. This also resists the perspectival, disconnected use of each facet that allows a view of only one facet, hegemonizes it and obscures all other facets or assumes the easy translatability (or reducibility) of one facet to another.

A comment on one of Paul Cezanne's paintings illustrates well what I mean by stereoscopically anatomizing our viewing justice and (re)assembling its (sur)faces: “We are asked to inhabit a scene where there is no familiar place to 'stand', no open prospect, no brightly lit stage. This is a stereoscopic space, an abstracted composition where near-space forms are left to define their own volumes and the spaces that surround them" [55] (p. 282). Where the perspectival representational regime, so celebrated in our times, fails, there the stereoscopic excels: the latter's contribution that cannot be covered by the perspectival concerns the non-linear, the volume [55] (p. 265) and the differentiated space [55] (p. 269)in my terms, the interconnectivity of perspectives and the zooming-in and zooming-out operations through which justice and its complex adjectival synergies and cracks become a palpable volume rather than disconnected and disassembled, hierarchized (sur)faces. More, "the stereoscopic assemblage open[s] up to view" "the anatomy of seeing" [55] (p. 265) and what is imperceptible or "dormant within natural[ized -M.P.] vision" (p. 265) of (in)justice.

However, neither should the stereoscopic be romanticized nor justice aestheticized. The course of transferring a metaphor from aesthetics to normativity requires constant caution. A stereoscopic optics does not efface perspective but claims some of its current discursive space in a mutually corrective and re-directive interplay. Interconnectivity, non-linear dynamics, (sur)faces interacting with and relying on one another create a whole that is not reducible to the sum of its parts. That this whole is fractured and elliptic becomes visible through my "that's not all" caveat; wholeness comes from the "illusion-making apparatus" [55] (p. 268). "Unlike photography" stereoscopy "persistently undermined expectations that it could mechanically reproduce the real" (268). Hence its doing justice to multiple (sur)faces, not only in their synergy and interconnectivity but also in their incompleteness, not only in the whole, but also in its cracks. Ultimately, it is a "parody of realist conventions" [55] (p. 268), hovering between down to earth perspectivalism or contextualism and God's eye view fantasies of plenitude or dangers of fullness and finalism.

Hence, that's not all.

Funding: This research received no external funding.

Conflicts of Interest: The author declares no conflict of interest.

\section{References}

1. Papastephanou, M.; Zembylas, M.; Bostad, I.; Oral, S.B.; Drousioti, K.; Kouppanou, A.; Strand, T.; Wain, K.; Peters, M.A.; Tesar, M. Philosophy of education in a new key: Education for justice now. Educ. Theory 2020, 1-16, early view.

2. Vine, D. Island of Shame; Princeton University Press: Princeton, NJ, USA, 2009.

3. New, W.S.; Merry, M.S. Is diversity necessary for educational justice? Educ. Theory 2014, 64, 205-225. [CrossRef]

4. Rozas, C. The possibility of justice: The work of Paulo Freire and difference. Stud. Philos. Educ. 2007, 26, 561-570. [CrossRef]

5. Papastephanou, M. The implicit assumptions of dividing a cake: Political or comprehensive? Human Studies 2004, 27, 307-334. [CrossRef] 
6. Dum, J. Ends, principles, and causal explanation in educational justice. Ethics Educ. 2017, 12, 184-200. [CrossRef]

7. Martin, C. Educational Justice and the Value of Knowledge. J. Philos. Educ. 2020, 54, 164-182. [CrossRef]

8. Martin, C.; Gilead, T. Intrinsic Goods and Distributive Justice in Education. Educ. Theory 2019, 69, 543-557. [CrossRef]

9. Ben-Shahar, T.H. Distributive justice in education and conflicting interests: Not (remotely) as bad as you think. J. Philos. Educ. 2015, 49, 491-509. [CrossRef]

10. Nielsen, L. Teach them to play! Educational Justice and the capability for Childhood play. Stud. Philos. Educ. 2020, 39, 465-478. [CrossRef]

11. Gilead, T. Promoting Distributive Justice in Education and the Challenge of Unpredictability. Stud. Philos. Educ. 2019, 38, 439-451. [CrossRef]

12. Schouten, G. Fair educational opportunity and the distribution of natural ability: Toward a prioritarian principle of educational justice. J. Philos. Educ. 2012, 46, 472-491. [CrossRef]

13. Sardoč, M.; Deželan, T. Talents and distributive justice: Some tensions. Educ. Philos. Theory 2020, 1-9.

14. Meyer, K. Talents, abilities and educational justice. Educ. Philos. Theory 2020, 1-11. [CrossRef]

15. Giesinger, J. Against selection: Educational justice and the ascription of talent. Educ. Philos. Theory 2020, 1-10.

16. Vopat, M.C. The belief in innate talent and its implications for distributive justice. Educ. Philos. Theory 2020, 1-14.

17. Foster, S.S. School choice and social injustice: A response to Harry Brighouse. J. Philos. Educ. 2002, 36, 291-308. [CrossRef]

18. Brighouse, H. Educational justice and socio-economic segregation in schools. J. Philos. Educ. 2007, 41, 575-590. [CrossRef]

19. Kotzee, B. Educational justice, epistemic justice, and leveling down. Educ. Theory 2013, 63, 331-350. [CrossRef]

20. Peterson, A. Civic republican social justice and the case of state grammar schools in England. Stud. Philos. Educ. 2018, 37, 167-179. [CrossRef]

21. Johnston, J.S. Prioritizing rights in the social justice curriculum. Stud. Philos. Educ. 2009, 28, 119-133. [CrossRef]

22. Sinha, S. The racialized body of the educator and the ethic of hospitality: The potential for social justice education re-visited. Stud. Philos. Educ. 2018, 37, 215-229. [CrossRef]

23. Nelsen, P.J. Growth and resistance: How Deweyan pragmatism reconstructs social justice education. Educ. Theory 2016, 66, 231-244. [CrossRef]

24. Ward, C. Theories of justice underpinning equity in education for refugee and asylum-seeking youth in the US: Considering Rawls, Sandel, and Sen. Ethics Educ. 2020, 15, 315-335. [CrossRef]

25. Bridges, D. Adaptive preference, justice and identity in the context of widening participation in higher education. Ethics Educ. 2006, 1, 15-28. [CrossRef]

26. Bull, B. Policy implications of social justice in education. Ethics Educ. 2009, 4, 141-152. [CrossRef]

27. Todd, S. Introduction to INPE Special Issue: Passion, Commitment and Justice in Education. Ethics Educ. 2014, 9, 39-41. [CrossRef]

28. Zembylas, M. 'Pedagogy of discomfort' and its ethical implications: The tensions of ethical violence in social justice education. Ethics Educ. 2015, 10, 163-174. [CrossRef]

29. Zembylas, M. (Un) happiness and social justice education: Ethical, political and pedagogic lessons. Ethics Educ. 2020, 15, 18-32. [CrossRef]

30. Martin, C. Transitional justice and the task of inclusion: A Habermasian perspective on the justification of aboriginal educational rights. Educ. Theory 2014, 64, 33-53. [CrossRef]

31. Aiston, S.J. Equality, justice and gender: Barriers to the ethical university for women. Ethics Educ. 2011, 6, 279-291. [CrossRef]

32. Kotzee, B.; Martin, C. Who should go to university? Justice in university admissions. J. Philos. Educ. 2013, 47, 623-641. [CrossRef]

33. Enslin, P.; Hedge, N. International students, export earnings and the demands of global justice. Ethics Educ. 2008, 3, 107-119. [CrossRef]

34. Hodgson, N. Narrative and social justice from the perspective of governmentality. J. Philos. Educ. 2009, 43, 559-572. [CrossRef]

35. Griffiths, M. Educational relationships: Rousseau, Wollstonecraft and social justice. J. Philos. Educ. 2014, 48, 339-354. [CrossRef]

36. Griffiths, M.; Murray, R. Love and social justice in learning for sustainability. Ethics Educ. 2017, 12, 39-50. [CrossRef]

37. Gewirtz, S. Towards a contextualized analysis of social justice in education. Educ. Philos. Theory 2006, 38, 69-81. [CrossRef]

38. Enslin, P. Democracy, social justice and education: Feminist strategies in a globalising world. Educ. Philos. Theory 2006, 38, 57-67. [CrossRef]

39. Snir, I.; Eylon, Y. Civic republicanism and education: Democracy and social justice in school. Stud. Philos. Educ. 2017, 36, 585-600. [CrossRef]

40. Kristjánsson, K. Beyond democratic justice: A further misgiving about citizenship education. J. Philos. Educ. 2004, 38, 207-219. [CrossRef]

41. Waghid, Y. Democratic citizenship, education and friendship revisited: In defence of democratic justice. Stud. Philos. Educ. 2008, 27, 197-206. [CrossRef]

42. Waghid, Y. Education, responsibility and democratic justice: Cultivating friendship to alleviate some of the injustices on the African continent. Educ. Philos. Theory 2007, 39, 182-196. [CrossRef]

43. Moon, S. Donghak (Eastern learning), self-cultivation, and social transformation: Towards diverse curriculum discourses on equity and justice. Educ. Philos. Theory 2017, 49, 1146-1160. [CrossRef]

44. Watts, M. Disproportionate sacrifices: Ricoeur's theories of justice and the widening participation agenda for higher education in the UK. J. Philos. Educ. 2006, 40, 301-312. [CrossRef] 
45. Joldersma, C.W. Education: Understanding, Ethics, and the Call of Justice. Stud. Philos. Educ. 2011, 30, 441-447. [CrossRef]

46. Drewery, W. Restorative practice in New Zealand schools: Social development through relational justice. Educ. Philos. Theory 2016, 48, 191-203. [CrossRef]

47. Applebaum, B. Social justice education, moral agency, and the subject of resistance. Educ. Theory 2004, 54, 59-72. [CrossRef]

48. Todd, S. Promoting a just education: Dilemmas of rights, freedom and justice. Educ. Philos. Theory 2007, 39, 592-603. [CrossRef]

49. Winter, C. Curriculum Knowledge, Justice, Relations: The Schools White Paper (2010) in England. J. Philos. Educ. 2014, 48, 276-292. [CrossRef]

50. Oral, S.B. Subject and justice: Žižek and Tiantai Buddhism. Educ. Philos. Theory 2018, 50, 1374-1375. [CrossRef]

51. Saito, N. What measures justice? What justifies happiness? Emersonian moral perfectionism and the cultivation of political emotions. Educ. Philos. Theory 2019, 51, 478-487. [CrossRef]

52. Jackson, L. 'Won't Somebody Think of the Children?' Emotions, child poverty, and post-humanitarian possibilities for social justice education. Educ. Philos. Theory 2014, 46, 1069-1081. [CrossRef]

53. Weinstein, M. Social justice, epistemology and educational reform. J. Philos. Educ. 1995, 29, 369-386. [CrossRef]

54. Keddie, A. Political justice, schooling and issues of group identity. Educ. Philos. Theory 2014, 46, 311-323. [CrossRef]

55. Bantjes, R. 'Perspectives bâtardes': Stereoscopy, Cézanne, and the Metapictorial Logic of Spatial Construction. Hist. Photogr. 2017, 41, 262-285. [CrossRef] 